\title{
Epidemiological study of lesions of the maxillofacial complex diagnosed by UNIME histopathology laboratory, Lauro de Freitas, Bahia
}

Andressa Chang Rodrigues Fernandes da Silva ${ }^{a}$, Isabela Bandeira ${ }^{b}$, Juliana Andrade Cardoso ${ }^{c}$, Manoela Carrera Martinez Cavalcante Pereira ${ }^{d}$

\begin{abstract}
OBJECTIVE: Epidemiological studies have great importance for oral health as they show the prevalence of various diseases in their respective environments, in addition to being able to characterize a given population. The objective of this work is to identify the prevalence of oral lesions in dental clinics of the Faculty of Agricultural Sciences and Health of the Metropolitan Union of Education and Culture (UNIME - Lauro de Freitas) in order to characterize the epidemiological profile of this population.

METHODS: The sample was composed by 434 histopathological reports of oral lesions diagnosed from 2003 to 2014, correlating them with the following variables: sex, age, type of biopsy (incisional/ excisional), histopathologic diagnosis, clinical suspicion and anatomical location.

REULTS: The epidemiological profile of patients affected by oral diseases had high percentage of females $(62.9 \%)$, with mean age of 39 years, and the most prevalent type of biopsy was the excisional (72.81\%). The data showed non-neoplastic proliferative processes as the most prevalent group of lesions $(24.2 \%)$, followed by odontogenic cysts $(17.5 \%)$. Lesions were most often presented in the mandible (19.6\%), followed by periapex (18.89\%), gum (11.75\%) and jugal mucosa $(9.45 \%)$.

CONCLUSION: The non-neoplastic proliferative processes can be prevented with simple measures of oral health.
\end{abstract}

Keywords: epidemiology; oral pathology; biopsy.

\section{Estudo epidemiológico das lesões do complexo bucomaxilofacial diagnosticadas no laboratório histopatológico da UNIME, Lauro de Freitas, Bahia}

\section{RESUMO}

INTRODUÇÃO: Os estudos epidemiológicos têm grande importância para a saúde bucal pois revelam a prevalência de diversas doenças no ambiente onde estão sendo executados, além de serem capazes de caracterizar uma determinada população. Este estudo tem como objetivo identificar a prevalência das lesões bucais nas clínicas odontológicas da Faculdade de Ciências Agrárias e da Saúde da União Metropolitana de Educação e Cultura (UNIME - Lauro de Freitas) com o intuito de caracterizar o perfil epidemiológico dessa população.

METODOLOGIA: A amostra foi constituída por 434 laudos histopatológicos de lesões bucais diagnosticadas no período de 2003 a 2014, correlacionando-as com as seguintes variáveis: sexo, idade, tipo de biópsia (incisional/ excisional), diagnóstico histopatológico, suspeita clínica e localização anatômica.

RESULTADOS: O perfil epidemiológico dos pacientes acometidos por patologias bucais obteve grande percentual em indivíduos do sexo feminino (62,9\%), com média de idade de 39 anos e o tipo de biópsia mais prevalente foi a excisional $(72,81 \%)$. Os dados evidenciaram os processos proliferativos não neoplásicos como o grupo de lesões mais prevalente (24,2\%), seguido dos cistos odontogênicos (17,5\%). As lesões se apresentaram mais frequentemente na mandíbula $(19,6 \%)$, seguida de periápice $(18,89 \%)$, gengiva $(11,75 \%)$ e mucosa jugal $(9,45 \%)$

CONCLUSÃO: Os processos proliferativos não neoplásicos podem ser prevenidos com medidas simples de saúde bucal.

Palavras-chave: epidemiologia; patologia bucal; biópsia a Dentistry from Faculdade UNIME de Ciências Agrárias e da Saúde, Lauro de Freitas, Bahia, Brazil bentistry from Faculdade Regional da Bahia UNIRB, Salvador, Bahia, Brazil

${ }^{c}$ Master of Stomatology from Pontifícia Universidade Católica do Rio Grande do Sul, Porto Alegre, Rio Grande do Sul, Brazil; Dentistry Professor from Faculdade UNIME de Ciências Agrárias e da Saúde, Lauro de Freitas, Bahia, Brazil d'PhD in Stomatology from the School of Dentistry of Piracicaba - FOP-UNICAMP, São Paulo, Brazil; Master of Stomatology from the Escola Bahiana de Medicina e Saúde Pública - BAHIANA, Salvador Bahia, Brazil; Assistant Professor in Pathology at Universidade do Estado da Bahia - Uneb, Salvador, Brazil; Adjunct Professor at Faculdade de Odontologia da Universidade Federal da Bahia Brazi

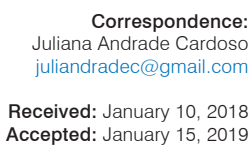

Conflict of Interests: The authors state that there re no financial and personal conflicts of interest that could have inappropriately influenced their work.

Copyright: (๑) 2018 da Silva et al licensee EDIPUCRS.

This work is licensed under a Creative Commons Attribution 4.0 International License.

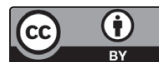




\section{INTRODUCTION}

In clinical practice, many lesions are often found in the oral cavity by dentists, ranging from the most common to the most rare, and having association with sociodemographic variables [1].

It is necessary to proceed with a well-designed clinical examination, and even, in some cases, the histopathological analysis in order to obtain a correct diagnosis, treatment, prognosis and later patient follow-up [2].

Subsequent to the diagnosis of lesions, it is possible to conduct an epidemiological study, which has fundamental importance for being able to point out the prevalence, incidence, extent and severity of the many diseases that affect the oral cavity, to establish preventive measures [3] From the data collected, one can plan, implement and evaluate health actions, as well as make inferences about the overall effectiveness of services; they also allow prevalence comparisons in different time periods and geographical areas [4].

Knowing well the importance of epidemiological studies, the objective of this work is to identify the prevalence of oral lesions in dental clinics of the Faculty of Agricultural Sciences and Health of the Metropolitan Union of Education and Culture (UNIME - Lauro de Freitas) in order to characterize the epidemiological profile of this population.

\section{METHODS}

It is a quantitative study of the sectional type, documentary and exploratory, having as research field the pathology laboratory of the Dentistry course of the Faculty of Agricultural Sciences and Health of the Metropolitan Union of Education and Culture (UNIME - Lauro de Freitas).

A total of 668 reports of oral lesions diagnosed and filed, from 2003 to 2014, by the pathology laboratory of UNIME that came from biopsies performed in the dental clinics of that institution was used for the execution of this study. Of these, 234 reports were excluded for not showing some of the following variables: sex, age, type of biopsy (incisional/ excisional), insufficient or inadequate specimen, clinical suspicion and anatomical location.

The research was approved by the Research Ethics Committee, under the protocol No. 1.216.464.

The collected data were tabulated through sheet registration in the program Microsoft Excel version 2010 in order to organize information, using statistical methodology, allowing inferences through the analyses of prevalence and the main characteristics of lesions in the oral cavity.

\section{RESULTS}

In total, 434 reports were analyzed, obtained through biopsy, of which $72.81 \%$ were of excisional type and $27.19 \%$ of incisional type (Figure 1). In both sexes, there was a greater amount of excisional biopsies $(\mathrm{F}=74.75 \%$ and $\mathrm{M}=69.56 \%$ ).
In determining the sex, it was found that $273(62.9 \%)$ diagnoses corresponded to females, while 161 (37.1\%) were related to males (Figure 2). The age of these individuals ranged between 06-87 years, with an average of 39 years, with the highest percentages concentrated in the 3rd and 4th decades of life (Table 1). The mean age of females was 39.6 years, ranging from 08 to 82 years, while for males that value was 38.2 years, ranging from 06 to 87 years.

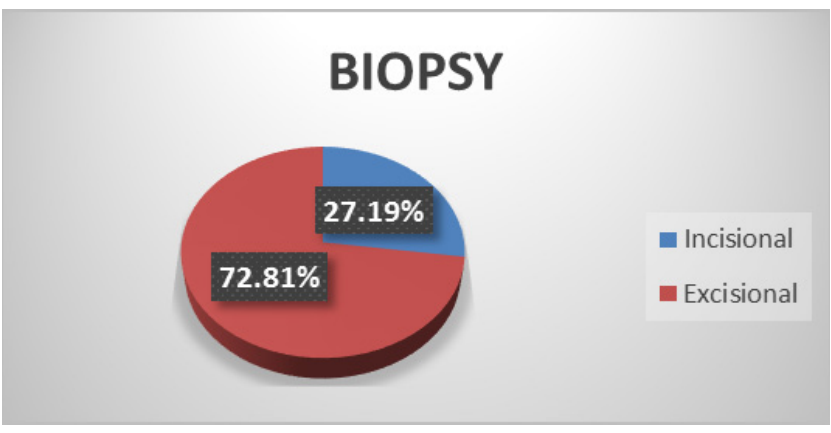

Figure 1. Distribution of oral lesions with respect to type of biopsy.

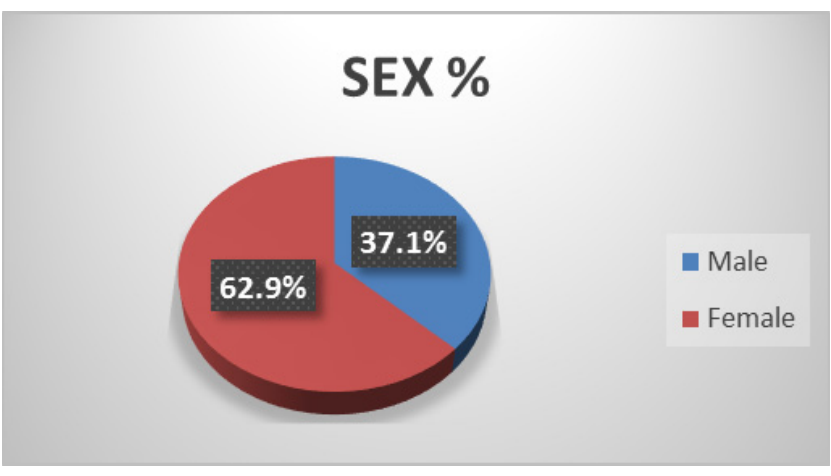

Figure 2. Distribution of oral lesions with respect to sex.

Table 1. Distribution of oral lesions with respect to age.

\begin{tabular}{ccc}
\hline AGE & N & $\%$ \\
$6-9$ & 7 & 1.61 \\
$10-19$ & 52 & 11.98 \\
$20-29$ & 75 & 17.28 \\
$30-39$ & 96 & 22.12 \\
$40-49$ & 74 & 17.05 \\
$50-59$ & 74 & 17.05 \\
$60-69$ & 40 & 9.22 \\
$70-79$ & 10 & 2.31 \\
$80-87$ & 6 & 1.38 \\
Total & 434 & 100 \\
\hline
\end{tabular}

The distribution of the anatomical location was performed according to the Table 2 . Thus, the most prevalent location was the mandible, corresponding to $19,6 \%$ of the cases. The periapex region was the second most affected location, 
with $18.89 \%$, followed by gum $(11.75 \%)$ and jugal mucosa $(9.45 \%)$. The least affected sites were labial commissure, tonsillar pillar and maxillary sinus $(0.46 \%, 0.46 \%$ and $0.23 \%$, respectively).

Classifying lesions in groups (Table 3), the non-neoplastic proliferative processes (NNPP) had higher prevalence, with $24.2 \%$ of the diagnosed cases. Among these, 57 (54.3\%) corresponded to inflammatory fibrous hyperplasia. The group of odontogenic cysts was the second most prevalent with $17.5 \%$, and the radicular cyst the lesion with the largest number of cases, $61.8 \%$ (47 cases). In females, the NNPP were the most prevalent, with 75 cases $(27.47 \%)$, while in males the most prevalent lesion group was the odontogenic cysts, with 38 cases $(23.6 \%)$.

Descriptive reports had a prevalence of $10.4 \%$ (45 cases), with females having twice the number of male cases.
The group classified as other lesions had hyperkeratosis, pericoronal follicle, junctional nevus and amalgam tattoo as the most frequent pathologies, its percentage being of $10.1 \%$, corresponding to 30 cases in females and 14 in males. Of these, 15 cases in females and 6 cases in males corresponded to lesions related to the pulp and the periapex.

In accordance with the highest percentage of prevalence, the following cases are observed: bone lesions (6.7\%), odontogenic tumors (5.3\%), lesions of inflammatory nature $(5.3 \%)$, lesions associated with the root apex $(4,8 \%)$, lesions from the salivary glands $(4.4 \%)$, non-odontogenic tumors $(3.9 \%)$, malignancies $(3.9 \%)$ having epidermoid squamous cell carcinoma the most prevalence histological type, potentially malignant lesions $(1.6 \%)$, lesions of cystic nature without specification $(1.2 \%)$, fungal lesions $(0.5 \%)$ and non-odontogenic cysts $(0.2 \%)$.

Table 2. Distribution of oral lesions with respect to their location.

\begin{tabular}{|c|c|c|c|c|c|c|}
\hline Location & $\mathrm{N}$ & $\%$ & $\mathrm{~F}$ & $\% F$ & M & $\% \mathrm{M}$ \\
\hline Mandible & 85 & $19.60 \%$ & 55 & $12.67 \%$ & 30 & $6.91 \%$ \\
\hline Periapex & 82 & $18.89 \%$ & 53 & $12.21 \%$ & 29 & $6.68 \%$ \\
\hline Gum & 51 & $11.75 \%$ & 36 & $8.29 \%$ & 15 & $3.46 \%$ \\
\hline Jugal mucosa & 41 & $9.45 \%$ & 26 & $5.99 \%$ & 15 & $3.46 \%$ \\
\hline Palate & 39 & $8.99 \%$ & 25 & $5.76 \%$ & 14 & $3.23 \%$ \\
\hline Upper jaw & 35 & $8.0 \%$ & 18 & $4.15 \%$ & 17 & $3.92 \%$ \\
\hline Alveolar ridge & 32 & $7.37 \%$ & 23 & $5.30 \%$ & 9 & $2.07 \%$ \\
\hline Tongue & 27 & $6.22 \%$ & 14 & $3.23 \%$ & 13 & $3.00 \%$ \\
\hline Lip & 24 & $5.53 \%$ & 15 & $3.46 \%$ & 9 & $2.07 \%$ \\
\hline Mouth floor & 13 & $2.99 \%$ & 6 & $1.38 \%$ & 7 & $1.61 \%$ \\
\hline Labial commissure & 2 & $0.46 \%$ & 1 & $0.23 \%$ & 1 & $0.23 \%$ \\
\hline Tonsillar pillar & 2 & $0.46 \%$ & 0 & 0 & 2 & $0.46 \%$ \\
\hline Maxilary sinus & 1 & $0.23 \%$ & 1 & $0.23 \%$ & 0 & 0 \\
\hline Total & 434 & $100 \%$ & 273 & $62.9 \%$ & 161 & $37.1 \%$ \\
\hline
\end{tabular}

Table 3. Frequency of the oral pathologies diagnosed with respect to gender.

\begin{tabular}{lccc}
\hline Diagnosed pathologies & Female & Male & Total (\%) \\
\hline Non-neoplastic proliferative processes & 75 & 30 & $105(24.2 \%)$ \\
\hline Odontogenic cysts & 38 & 38 & $76(17.5 \%)$ \\
\hline Descriptive reports & 30 & 15 & $45(10.4 \%)$ \\
Other lesions & 30 & 14 & $44(10.1 \%)$ \\
Bone lesions & 25 & 4 & $29(6.7 \%)$ \\
Odontogenic tumors & 14 & 9 & $23(5.3 \%)$ \\
Lesions of inflammatory nature & 17 & 6 & $23(5.3 \%)$ \\
Lesions associated with the root apex & 15 & 6 & $21(4.8 \%)$ \\
\hline Salivary gland lesions & 9 & 10 & $19(4.4 \%)$ \\
Non-odontogenic tumors & 10 & 7 & $17(3.9 \%)$ \\
Malignancies & 5 & 12 & $17(3.9 \%)$ \\
\hline Potentially malignant lesions & 1 & 6 & $07(1.6 \%)$ \\
Lesions of cystic nature without specification & 4 & 1 & $05(1.1 \%)$ \\
\hline Fungal lesions & 0 & 2 & $02(0.5 \%)$ \\
\hline Non-odontogenic cysts & 0 & 1 & $01(0.2 \%)$ \\
\hline
\end{tabular}




\section{DISCUSSION}

The correct clinical diagnosis and the knowledge of the frequency and prevalence of oral lesions are essential in dentistry. This requires a very careful and detailed anamnesis to be related to the clinical aspects $[5,6]$.

Along with these clinical features, the histopathological examination is a tool that will guide the conduct of the dentist in the treatment of oral lesions [7]. This study has observed a lack of attention on the complete filling of the biopsy records, discarding thus 234 reports. Therefore, it is important to educate students and professors about the importance of the complete filling of the patient's data in the biopsy form for diagnostic accuracy.

The biopsy is a simple, reliable and easy-to-perform procedure which aims to provide a suitable biological material for the performance of microscopic examination, thus enabling the final diagnosis [8]. In this study, there was prevalence of excisional biopsies (72.81\%) compared to incisional biopsies $(27.19 \%)$, and these data are similar to those described by Silva et al. [9], which justifies that professionals opt for this procedure because most of the oral lesions are small, and it is often the definitive treatment for these lesions. Some reports were not conclusive by fact that the specimens were insufficient or inadequate to perform the anatomopathological examination and therefore were excluded from the sample, which shows the necessity of this surgical technique. Other factors that should be considered by clinicians are the specimen fixation techniques, packaging and transport of parts, since they represent a great possibility of error [10].

This study obtained a woman:man ratio of 1.47:1 as well as the studies by Xavier et al. [11], Bertoja et al. [12], Prado et al. [13], Melo et al. [14], Andrade et al. [15], in which females were most affected by oral lesions. This prevalence is due to the fact that women are more concerned with their appearance and health than men, resulting in greater demand for health care services by females $[9,11,12]$. Few studies oppose to this result, such as Neto et al. [3], in which that ratio was $1: 1.42$.

With regard to age, it was found the predominance of individuals in the $3 \mathrm{rd}$ and 4 th decades of life, with a mean age of 39 years. These age and mean age data are in agreement with what was found in the literature $[3,13,16,17]$, and in disagreement with the study of Melo et al. [14], who pointed people aged less between the biopsied individuals.

The most affected location in this study were mandible, but there was a some difficulty in the interpretation of this variable because no exact specification the location of the biopsy plug, which only confirms the importance of closing correctly these chips because each information is very valuable to the pathologist close the diagnosis and contribute to future studies. In an epidemiological study of 30 cases of maxillofacial lesions, conducted by Silva [9], the most affected anatomical sites were jugal mucosa, lower lip, lateral border of the tongue and periapical region of molars. Despite this variation of results in relation to previous studies exposed in the literature, the author states, finally, that one must recognize the importance that these data bring to the pathologist, as they enable a comparison and a differentiation of the affected tissues from the histological features each anatomical region has.

The non-neoplastic proliferative processes was the group that had the highest number of cases $(n=105)$, which corroborates the data found in other studies $[3,12,14,18,19]$. Among the NNPP, fibrous hyperplasia, pyogenic granuloma and giant cell lesions are the most frequent and are usually resulting from traumatic factors or local irritants [20]. Lack of access to dental treatment of good quality associated with prevalence of more advanced age leads individuals to use ill-fitting dentures, which explains the higher number of cases of fibrous hyperplasia. Moreover, the lack of guidance on oral hygiene also contributes to the appearance of these lesions, such as pyogenic granuloma [10]. In this study, more than half of the cases of NNPP affected females, a fact that coincides with the research conducted by Palmeira et al. [20], where $73 \%$ of the cases belonged to women. Linked to the fact, already mentioned, that women are more thoughtful regarding oral health, seeking specialized care more than men, it is also considered that the systemic factors inherent to females favor the appearance of oral pathologies $[10,20,21]$.

Odontogenic cysts (OC) appeared as the second most prevalent group of this study. In relation to sex, there was no difference, since half the cases of OC corresponded to females and half corresponded to males. Among the 76 cases of OC, $57.7 \%$ were cysts of inflammatory nature, as described in the literature $[3,14]$. These cysts are related to the presence of necrosis and infections of the pulp tissue $[22,23]$.

A data to be reviewed for being a relevant result, despite the low prevalence, was the higher incidence of potentially malignant lesions and malignant lesions in males. In the group of malignant lesions, of the 17 diagnosed cases, 12 corresponded to males. In the group of potentially malignant lesions, from the total of 7 cases diagnosed, 6 corresponded to males. This man:woman ratio can be explained by the fact that men consume more tobacco and alcohol, which are risk factors of oral cancer [24]. Nonetheless, studies have proved that there was a reduction in this ratio, since women started to expose more to the alcohol-tobacco association in virtue of the change in social habits $[24,25]$. This finding is confirmed by the INCA data, which, for 2014, showed an estimate of 2.8 cases in men for every woman diagnosed [26], while the estimated risk for 2016 is of 2.6 cases in males for every case diagnosed in women [27]. Thus, it is highlighted the importance of educating the patient to perform oral selfexamination, giving oral hygiene instructions and advising the adoption of favorable habits in order to prevent and diagnose early lesions of the oral cavity [10].

\section{CONCLUSIONS}

The epidemiological profile of the population with biopsied oral lesions archived in the pathology laboratory of 
the Dentistry course of the Faculty of Agricultural Sciences and Health, from 2003 to 2014, was characterized by female individuals, with mean age of 39 years, and the nonneoplastic proliferative processes were the most prevalent lesions, the mandible being the most commonly affected location.

The results indicate that a greater commitment on the part of dentists in the guidance on the appropriate use of dentures and their time of use, as well as their hygiene, is necessary to contribute to reducing the incidence of fibrous hyperplasia. The non-neoplastic proliferative processes can be prevented with simple measures of oral health.

The correct diagnosis of oral lesions will depend on the skills and knowledge of the acting professional. Adding to it, the correct completion and full detailing of the biopsy form is necessary, as it will be of great importance in establishing the diagnosis, treatment and prognosis to be performed.

\section{REFERENCES}

1. Conceição LD, Magrin T, Gomes APN, Araújo LMA. Retrospective study of language in biopsies - Epidemiological aspects. RFO-UPF 2010;15(1): 11-9.

2. Boraks S. Oral Diagnosis. $3^{a}$ edição. São Paulo: Artes Médicas; 2001.

3. Neto BD, Medrado AP, Reis SRA. Epidemiological survey of histopathologic diagnosis of a reference center in oral and maxillofacial pathology in a period of 10 years. Ver Bahiana Odonto 2012;3(1):3-15

4. Oliveira AGRC, Unfer B, Costa ICC, Arcieri RM, Guimarães LOC, Saliba NA Epidemiological surveys in oral health: methodological analysis proposed by the World Health Organization. Rev Bras EpidemioL 1998;1 (2):177-89. https://doi.org/10.1590/S1415-790X1998000200008

5. Alves JR, Hida M, Nai GA. [Clinical and pathological diagnosis: disagreements]. Rev Assoc Med Bras 2004;50(2):178-81. https://doi. org/10.1590/S0104-42302004000200035

6. Vaz DA, Valença DL, Lopes RBM, Silva AVC, Pereira JRD. Concordance between clinical and histological diagnosis of Oral Pathology Laboratory of Pernambuco Dental School. RPG Rev Pós Grad 2011;18(4):236-43.

7. Trevisan B, Wagner JCB, Volkweis MR. Histopathological diagnosis of oral lesions. The experience of a surgical service and Maxillofacial. RFO-UPF 2014;18(1):55-60

8. Aquino SN, Martelli DRB, Borges SP, Bonan PRF, Martelli Junior H. Concordance between clinical and histopathological diagnosis of oral lesions. Rev Gaúcha Odontol 2010;58(3):345-9

9. Silva TFA, Souza RB, Rocha RD, Araújo FAC, Morais HHA Survey of biopsies performed at the University of Rio Grande do Norte Dentistry course Maxillo- Facial Surgery Service. Rev Cir Traumatol BucoMaxilo-Fac 2011;11(2):91-100

10. Simões CA, Lins RC, Henriques ACG, Cazal C Castro JFL. Prevalence of diagnosed lesions in the maxillofacial region in the laboratory of oral pathology at the Federal University of Pernambuco. IJD 2007;6(2):35-8
11. Xavier JC, Andrade SC, Arcoverde CAL, Lucena KCR, Cavalcanti UDNT, Carvalho AAT. Epidemiological survey of oral lesions presented by patients seen at the Stomatology Service of the Federal University of Pernambuco during the period from January 2006 to July 2008. IJD 2009;8(3):135-9.

12. Bertoja IC, Tomazini JG, Braosi APR, Reis LFG, Giovanini AFR. Prevalence of oral lesions diagnosed by histopathology Laboratory UnicenP. RSBO 2007;4(20):41-6

13. Prado BN, Trevisan S, Passarelli DHC. Epidemiological study of oral lesions in the period of 05 years. Rev Odontol Univ Cid Sao Paulo 2010;22(1):25-9.

14. Melo AR, Pires SMS, Ribeiro CF, Júnior RLCA, Melo AUC. Prevalence of oral lesions diagnosed in oral pathology laboratory at the University Tiradentes (2002-2010). Rev Cir Traumatol Buco-Maxilo-Fac 2013;13(2):109-14.

15. Andrade AS, Souza DCO, Barbosa KS,Grossmann SMC, Magalhães SR. Prevalence of oral lesions and normality changes in patients of Dental School, UNINCOR-BH. RUVRD 2014;12(1):785-93

16. Rocha DAP, Oliveira LMM, Souza LB. Benign tumors of the oral cavity: epidemiological study of 21 years (1982-2002 ). Rev Odontol Univ Cid Sao Paulo 2006;18(1):53-60

17. Vier FV, Rockenbach MIB, Yurgel LS, Cherubini K, Figueiredo MAZ. Histopathological diagnosis of Stomatology Department of Pathology Laboratory of PUCRS, in the years 2000-2002 and its relationship with the clinical diagnosis. Rev Odonto Science 2004;19(46):382-8

18. Souza JGS, Soares LA, Moreira G. Frequency of oral pathologies diagnosed in University Dental Clinic. Rev Cubana Estomatol 2014;51(1):43-54

19. Souza JGS, Soares LA, Moreira G. Concordance between clinical and histopathological diagnosis of oral lesions diagnosed in University Clinic. Ver Odontol UNESP 2014;43(1):30-5. https://doi.org/10.1590/S180725772014000100005

20. Palmeira ARBLS, Florêncio AG, Silva Filho JP, Silva UH, Araújo NS. Nonneoplastic proliferative lesions: a ten-year retrospective study. Rev Gaúcha Odontol 2013;61(4):543-7.

21. Neville BW, Damm DD, Allen CM, Bouquot JE. Pathology Oral and Maxillofacial. 3a ed. Rio de Janeiro: Elsevier; 2009

22. Nanami R, Sampaio C, Olivete J, Pizzatto E, Moresca R, Giovanini AF. Prevalence of maxillary cysts diagnosed in a Brazilian referral center. RSBO 2009;6(2):143-6.

23. Araújo FAC, Landim FS, Rocha NS, Caubi AF, Morais HHA. Treatment of extensive inflammatory cyst in the maxilla - report case. Rev Cir Traumato Buco-maxilo-fac 2013;13(2):81-5

24. Brener S, Jeunon FA, Barbosa AA, Grandinetti HAM. Carcinoma of oral squamous cell carcinoma: a literature review of the patient's profile, clinical stage and proposed treatment. Rev Bras Cancerol 2007;53(1):63-9.

25. Filho FSA, Sobrinho JA, Rapoport A, Carvalho MB, Novo NF, Juliano Y. Study demographic and occupational variables and co- carcinogenetics in squamous cell carcinoma of the tongue base in women. Rev Bras Otorrinolaringol 2003;69(4):472-8. https://doi.org/10.1590/S003472992003000400006

26. National Cancer Institute (INCA/MS ) [homepage on the Internet]. Estimate 2014: Cancer Incidence in Brazil [cited 2015 Nov ]. Available from: http:// www.inca.gov.br

27. National Cancer Institute (INCA/MS ) [homepage on the Internet]. Estimate 2016: Cancer Incidence in Brazil [cited 2016 Feb ]. Available from: http:// www.inca.gov.br 